\title{
Os prefácios da Introdução ao Cristianismo de J. Ratzinger: uma análise teológica e social do "mundo de hoje"1
}

\author{
The prefaces of J. Ratzinger's Introduction \\ to Christianity: \\ a theological and social analysis of the \\ "world of today"
}

Rudy Albino de Assunção

\section{Resumo}

A obra Introdução ao Cristianismo de Joseph Ratzinger conta com três prefácios (dos anos 1967, 1969 e 2000). Interessante notar que o teólogo alemão se dedicou, particularmente no último deles, a descrever o contexto sociocultural - ideológico ou filosófico-político, pode-se dizer - que emergiu nos trinta anos que se seguiram à primeira aparição da obra. Ou seja, ele pressupõe um diagnóstico do tempo no qual a fé deve ser anunciada, transmitida e, também, um olhar crítico pelos quais a teologia se enveredou neste período. Nesse sentido, o livro é também uma introdução ao que é o mundo contemporâneo ou, ainda, uma análise da relação entre fé cristã e mundo. O primeiro capítulo da Introdução se intitula precisamente "Crer no mundo de hoje". Assim sendo, esta pesquisa visa apresentar a concepção de mundo de hoje exposta na obra, com particular atenção às correntes de

\footnotetext{
${ }^{1} \mathrm{O}$ presente trabalho integra a produção do estágio pós-doutoral em Teologia realizado na PUC-Rio, com a supervisão do Prof. Dr. Antonio Luiz Catelan Ferreira.
} 
pensamento que o caracterizam. E para completar a exposição, o artigo fará ligações entre a descrição realizada por Ratzinger na Introdução com pronunciamentos realizados durante o seu pontificado, como as respostas dadas por ele no seu Encontro com o Clero de Belluno-Feltre e Treviso, no dia 24 de julho de 2007, no qual faz referência aos mesmos eventos e datas que analisou no prefácio do ano 2000. Assim, o leitor poderá constatar a visão de mundo com a qual a Igreja deve dialogar (ou se confrontar) na perspectiva de J. Ratzinger-Bento XVI.

Palavras-chave: J. Ratzinger. Igreja. Cristianismo. Mundo de hoje.

\begin{abstract}
Joseph Ratzinger's Introduction to Christianity has three prefaces (from the years 1967, 1969 and 2000). It is interesting to note that the German theologian dedicated himself, particularly to the last one, to describe the sociocultural context - ideological or philosophical-political, it may be said - that emerged in the thirty years that followed the first appearance of the work. That is, it presupposes a diagnosis of the time in which faith must be announced, transmitted and, also, a critical look at which theology took in this period. In this sense, the book is also an introduction to the contemporary world or even an analysis of the relationship between Christian faith and the world. The first chapter of the Introduction is precisely entitled "Believe in the world of today". Thus, this research aims to present the conception of the world of today exposed in the work, with particular attention to the currents of thought that characterize it. And to complete the exposition, the article will link Ratzinger's description in the Introduction with pronouncements made during his pontificate, such as the answers given by him at his meeting with the Clergy of Belluno-Feltre and Treviso on July 24 2007, in which he refers to the same events and dates that he analyzed in the preface of the year 2000. Thus, the reader will be able to see the worldview with which the Church must dialogue (or confront) from the perspective of $J$. Ratzinger-Benedict XVI.
\end{abstract}

Keywords: J. Ratzinger. Church. Christianity. World of today. 


\section{Introdução}

Nosso dever é introduzir nessa terra incógnita os jovens estudantes, que nela não viveram desde a infância, que não fruíram do seu sol nem comeram do seu pão. ${ }^{2}$

A obra Introdução ao Cristianismo. Preleções sobre o Símbolo Apostólico $^{3}$ de Joseph Ratzinger - cujo surgimento data de 1968 - conta com três prefácios principais: dos anos 1967,1969 e $2000 .{ }^{4}$ Ou seja, ela possui um prefácio do ano da redação e um posterior, de 1969 (apenas um ano depois de sua publicação), referente à décima edição, o que testemunha o sucesso de suas vendas. No entanto, no ano 2000, Ratzinger acrescentou um terceiro prefácio, significativamente mais longo que os dois primeiros. E é interessante notar que o teólogo alemão se dedicou, particularmente neste último, a descrever o contexto sociocultural - ideológico ou filosófico-político, pode-se dizer - que emergiu nos trinta anos que se seguiram à primeira aparição da obra. O livro em tela é, nesse sentido, também uma introdução à Weltanschauung moderna. O primeiro capítulo da Introdução dá testemunho disso: "Crer no mundo de hoje".

É importante acrescentar que, em 2014, Bento XVI acrescentou um novo prólogo/prefácio à obra, no qual mais uma vez situa a sua Introdução no debate teológico do seu tempo. ${ }^{5}$ A ele também nos dedicaremos, embora o foco principal desta pesquisa esteja sobre os três textos principais supramencionados.

A correta hermenêutica da Introdução passa, portanto, pela acurada análise sinótica dos seus prefácios, pois eles são as lentes que nos ajudam

\footnotetext{
${ }^{2}$ ADAM, K., A essência do catolicismo, p. 15.

${ }^{3}$ Para uma primeira visão geral da Introdução ao Cristianismo ver a obra organizada por ocasião dos seus 40 anos de publicação: CHARAMSA, K.; CAPIZZI, N., La voce dela fede cristiana. Para uma breve alusão à origem da obra, consulte-se GUERRIERO, E., Servitore di Dio e dell'umanità, p. 134-140.

${ }^{4}$ Em RATZINGER, J., Obras Completas IV, p. 8-11, apareceram dois outros prefácios para contextos linguísticos específicos: um para a edição coreana (1974) e outro para a eslovena (1975), quando Ratzinger já estava em Regensburg. Os prefácios referidos em termos de novidade só acrescentam um detalhe - uma curiosidade - acerca da inspiração que deu impulso à escrita da obra: Ratzinger se sentou para comer, certa vez, diante de um estudante de medicina persa, o qual lhe interpelou em que consistia a fé cristã.

${ }^{5}$ RATZINGER, J., Obras Completas IV, XVII-XX.
} 
a entender a gênese do texto e sua atualidade depois de trinta e, agora, de cinquenta anos. Equivocar-se-iam aqueles que pensassem que se tratam de textos de menor importância dentro do conjunto do livro, pois os temas que eles trazem evidenciam a atualidade da obra, a sua clarividência e dão a chave de leitura dos contextos de sua produção e de sua possível propagação (do livro e do cristianismo que busca apresentar).

Para completar a exposição, esta pesquisa fará ligações entre a descrição realizada por Ratzinger na Introdução com pronunciamentos realizados durante o seu pontificado, como as respostas dadas por ele, como papa Bento XVI, no seu Encontro com o Clero de Belluno-Feltre e Treviso, no dia 24 de julho de 2007, no qual faz referência aos mesmos eventos e datas que analisou no prefácio do ano 2000.

Meu aprofundamento passará, portanto, por níveis de análise: do pano de fundo ideológico do ambiente universitário no qual a Introdução foi escrita (nível do contexto); a mudança de perspectiva do prefácio de 1967 para o de 2000 (nível sócio-religioso); um olhar mais detido sobre a mudança epocal iniciada no ano de 1968 e modificada no ano de 1989 (nível sócio-político).

Este artigo busca, portanto, apresentar o diagnóstico do tempo (do mundo de hoje) no qual a fé deve ser anunciada, transmitida, comunicada e, é claro, a descrição dos caminhos da teologia nas últimas décadas de acordo com J. Ratzinger-Bento XVI.

\section{De Tübingen a Roma}

Uma observação ligeira sobre os lugares a partir dos quais Ratzinger falou: primeiramente Tübingen e, depois, no início no novo século, no ano 2000, já em Roma. Duas posições diferentes: antes, professor na universidade tubinguesa (de 1966 a 1969) e, depois, Prefeito da Congregação para a Doutrina da Fé (de 1982 a 2005). ${ }^{6}$

A obra Introdução ao Cristianismo foi escrita sobretudo em 1967, como uma série de preleções para o semestre de verão em Tübingen. Antes, é preciso lembrar que esta Introdução era um projeto aventado há uma década por Ratzinger e que pretendia ser um curso aberto não só aos estudantes de Teologia, centrado no conteúdo e no significado da fé cristã, mas para todos que quisessem ouvi-las. Assim, às suas aulas

\footnotetext{
${ }^{6}$ Em 1969 ele passou para a Universidade de Regensburg, na Bavária e em 1977 é nomeado Arcebispo de München e Freising (1977-1981).
} 
muito concorridas assistiam, portanto, párocos, religiosos e simples fiéis. Nas aulas que deram origem à obra - gravadas pelo seu assistente, Peter Kuhn, o que curiosamente assinala o nascimento do livro com o apoio da técnica moderna - "Ratzinger tenta repropor a razoabilidade da fé dentro do terremoto que estava atingindo os paradigmas culturais compartilhados nas sociedades ocidentais".?

No seu prólogo de 2014 Bento XVI citava dois grandes acontecimentos que ensejaram a escrita de sua obra. Para ele, o primeiro, está relacionado à exegese bíblica. No pós-Concílio sobretudo ocorrera uma reviravolta na relação entre Igreja e Sagrada Escritura. Ou seja, uma imposição unilateral do método histórico-crítico, com um consequente esquecimento da unidade da Bíblia e da importância da interpretação bíblica segundo a regula fidei. O segundo foi a queda do tomismo - pujante no início do século XX - como filosofia comum da teologia católica ${ }^{8}$.

Tal reviravolta deu lugar a que correntes de pensamento? Ratzinger o mostra em sua autobiografia. O ambiente teológico católico em Tübingen - "a grande Meca da teologia", ${ }^{9}$ desde o século XVI de natureza protestante e com uma faculdade teológica católica de apenas 150 anos - era profundamente marcado pela perspectiva histórica e ecumênica, da qual Ratzinger expressamente desejava se aproximar. ${ }^{10}$ Mas o ambiente universitário tornouse mais politizado e influenciado pelo marxismo. Ou seja, não havia como separar a discussão teológica da política. Em sua autobiografia parcial, Ratzinger sintetizava do seguinte modo a mudança de paradigma ideológico a que assistia em Tübingen:

Agora, o esquema existencialista desmoronava, quase de um dia para o outro, sendo substituído pelo marxista. Agora Ernst Bloch lecionava em Tubinga, ridicularizando Heidegger como sendo pequeno-burguês; para a Faculdade Teológico-Evangélica foi nomeado, quase ao mesmo tempo da minha chegada, Jürgen Moltmann, que em seu fascinante livro Teologia da Esperança tinha concebido, partindo de Bloch, uma teologia nova e totalmente diferente. ${ }^{11}$

\footnotetext{
${ }^{7}$ VALENTE, G., Ratzinger professore, p. 130.

${ }^{8}$ RATZINGER, J., Obras Completas IV, XVIII-XX.

${ }^{9}$ BLANCO, P., Benedicto XVI, p. 191.

${ }^{10}$ BLANCO, P., Benedicto XVI, p. 193.

${ }^{11}$ RATZINGER, J., Lembranças da minha vida, p. 116.
} 
Quando a obra foi escrita era vertiginoso o crescimento do marxismo, portanto. Como a citação acima deixou claro a aproximação entre marxismo e teologia na década de 60 estava consumada, como bem exemplificam a Teologia da Esperança (1964) de Jürgen Moltmann no campo protestante e a Teologia Política (1968) de Johann Baptist Metz ${ }^{12}$ no campo católico. E estas duas teologias contribuíram decisivamente para o desenvolvimento da Teologia da Libertação (TdL), que emergiu entre 1968 e $1972 .{ }^{13}$ Está longe, portanto, de ser uma coincidência que a análise de Ratzinger em 1967 na Introdução fosse o confronto direto com a emergência de um paradigma, de uma ideologia totalizante e, no início do século, ele pudesse avaliar criticamente os resultados desta hegemonia ideológica no campo teológico e político, como o fez ao se referir ao ano de 1989 e ao período que se segue a ele, como veremos mais adiante.

É imprescindível recordar que no capítulo 1 da Introdução o marxismo aparece caracterizando a segunda fase de desenvolvimento do espírito do pensamento moderno, a saber, a guinada para o pensamento técnico: aquele em que prevalece o faciendum, o que pode ser feito pelo ser humano como a única coisa que pode ser "verdadeiramente" conhecida. E trinta anos depois, Ratzinger pode olhar criticamente para os resultados dessa ascensão, sobretudo para os efeitos do seu crescimento dentro do seu campo de saber por meio da TdL.

O jovem teólogo antes criticava o marxismo pela concentração exclusiva no resultado da ação revolucionária da coletividade (do proletariado), ou seja, no excessivo acento na ação humana; agora, ele critica a TdL pela "ausência de fato da ideia de Deus", ${ }^{14}$ o que impactou fatalmente na imagem de Cristo que ela transmite. Ele asseverava sobre a TdL: "Não que se tenha negado a existência de Deus - de modo algum. Ele era dispensável na 'realidade' que exigia toda a atenção. Carecia de função". ${ }^{15}$ Deste modo, à ideia de Deus faltava praticidade; ela, no fim das contas, não serviria para a meta última da revolução, que é a transformação radical do mundo, das suas estruturas injustas. Para Ratzinger, ao contrário, "Deus é prático"16 e a fé nele é decisiva para a ação no mundo.

\footnotetext{
${ }^{12}$ As edições brasileiras são: MOLTMANN, J., Teologia da Esperança e METZ, J. B., Teologia Política.

${ }^{13}$ MONDIN, B., Os teólogos da libertação, p. 32; GIBELLINI, R., A Teologia do Século XX, p. 301.

${ }^{14}$ RATZINGER, J., Introdução ao Cristianismo, p. 14.

${ }^{15}$ RATZINGER, J., Introdução ao Cristianismo, p. 14.

${ }^{16}$ RATZINGER, J., Introdução ao Cristianismo, p. 15.
} 
Em outras palavras, a crítica de Ratzinger em 1967 ao marxismo se aplica, no fim das contas, à TdL: se naquela época ele apontava tão precocemente o equívoco de determinadas correntes teológicas do pós-Vaticano II que excluíam o núcleo da fé em nome de uma equívoca liberdade, ele indicava agora no ano 2000 que a TdL, ao colocar Deus em segundo plano, exclui assim o essencial da teologia e, é claro, da fé da Igreja. A "barra de ouro" é, mais uma vez, descartada.

O foco do terceiro prefácio da Introdução não é ser um panfleto contra a TdL, pois a sua perspectiva de análise é mais universal, pois abarca desenvolvimentos políticos, econômicos e religiosos da segunda metade do milênio passado, como os tópicos deste artigo evidenciam.

No entanto, a radicalização de alguns pressupostos seus a tornou exemplar de um processo de transformação do ambiente teológico que significou, para o cardeal alemão, uma perda para a fé, pela aplicação da perspectiva marxista sobretudo. Isso ficou bem evidente na sua apresentação do livro entrevista Deus e o mundo anos depois, quando ele mostra que a renúncia à verdade significou a renúncia à ortodoxia em favor do primado da ortopraxis. ${ }^{17}$

Ratzinger, no início do novo milênio, ainda olha para o campo da teologia e sobre os efeitos de longo prazo do marxismo - a ocultação moderna de Deus ou a grave relegação (em bom português "punição com desterro") do Criador para a esfera da intimidade, o "lugar da fé" exilada. Isso já nos aponta para o tipo de análise que Ratzinger faz, que extrapola a teologia e nos encaminha para uma leitura fundada nas ciências sociais da religião.

\section{Entre Teologia e Sociologia da Religião}

O prefácio de 1967 - para retomar a primeira apresentação da obra estava centrado na leitura crítica que Ratzinger fazia dos desenvolvimentos da teologia moderna, o que ele, como teólogo profissional, nunca perdeu de vista. Nele Ratzinger deixa claro o objetivo seminal da obra, que é "ajudar a compreender de uma nova maneira a fé como possibilidade de uma verdadeira existência humana no mundo de hoje..." ${ }^{18} \mathrm{O}$ primeiro capítulo, já mencionado, esclarece justamente na visão ratzingeriana deste mundo na quarta parte: $O$ limite da compreensão moderna da realidade e o lugar da fé.

\footnotetext{
${ }^{17}$ RATZINGER, J.; SEEWALD, P., Deus e o mundo, p. 11.

${ }^{18}$ RATZINGER, J., Introdução ao Cristianismo, p. 26 (itálico nosso).
} 
Sua análise estava precisamente focada na ideia de que o tesouro da fé - a barra de ouro do "Joãozinho, o Felizardo"19 - havia sido descartado pela teologia contemporânea e, portanto, ela se concentrava no debate interno ao círculo dos especialistas. O prefácio de setembro de 1969 (último ano de Ratzinger em Tübingen, recordemos), de apenas uma página, só falou das respostas que Ratzinger deu aos seus críticos na revista Hochland e nele Ratzinger só acentuou a intenção ecumênica da obra.

Já no prefácio do ano 2000 a sua perspectiva se amplia. Do prefácio de 1967 ao do ano 2000 há um alargamento de horizonte do teólogo bávaro. A sua preocupação por uma verdadeira e eficaz Introdução ao Cristianismo vai da discussão sobre a teologia moderna para a uma análise do mundo moderno. ${ }^{20}$ É claro que o debate teológico não saiu do horizonte de Ratzinger, o que se expressa claramente na sua análise da emergência da TdL.

Sua posição como Prefeito da Congregação para a Doutrina da Fé, desde sua "atalaia romana" lhe permitiu, entretanto, observar os caminhos tomados pelo cristianismo em todo o mundo, com particular atenção sobre a situação da fé e da teologia em nosso tempo. Sua atuação no caso da TdL na década de 80 deu-lhe material para, depois, no ano 2000, apresentar os efeitos desta corrente latino-americana na vida da Igreja.

Deste modo, creio que a maior parte do texto (do ano 2000) - sem perder sua natureza teológica - é permeada por uma verdadeira leitura sociológica, ou dito de outro modo, embasada em determinada perspectiva oriunda da sociologia da religião/do cristianismo no mundo moderno. Um breve sumário dos temas do prefácio em tela tranquilamente atesta isso: nele aparecem observações fundamentais sobre os anos de 1968 e 1989; sobre a relação entre Igreja e mundo, com direta alusão ao Vaticano II; sobre a Teologia da Libertação e a questão de Deus, amiúda citada aqui; a redescoberta da religião na década de 60 e a consequente relativização (homologação) religiosa que aí se iniciou, com o interesse ocidental pelas religiões asiáticas (budismo e hinduísmo). O texto reflete as implicações desta análise sociológica sobre a fé em Cristo (cristologia) e a crença num Deus pessoal (temática propriamente

\footnotetext{
${ }^{19}$ Em Tübingen Ratzinger foi colega de Hans Küng, o teólogo suíço controvertido, que em 1977 perdeu a missio canonica por conta de suas posturas sobre o primado papal. Isso ajuda a entender que a associação - há muito negada por Ratzinger - de que o "Joãozinho feliz" da primeira página da Introdução seja uma referência "velada" a Hans (João) Küng (RATZINGER, J.; SEEWALD, P., O sal da terra, p. 64).

${ }^{20}$ Uma análise global e detalhada da concepção ratzingeriana-beneditina sobre a modernidade pode ser encontrada em ASSUNÇÃO, R. A., O Papa precisa do marxismo?, p. 1042-1059.
} 
teológica), até o ponto de terminar com uma reflexão sobre o desmoronamento das bases éticas cristãs na modernidade. Dito de outro modo: ele verifica as condições de possibilidade para o tratamento da questão de Deus e de Cristo, que é central na Introdução.

E este texto - pode-se dizer - reflete as mesmas interrogações nos estudos de Ratzinger sobre a Gaudium et spes, pois ele retoma logo no início do prefácio a temática da relação entre Igreja e mundo e da intenção conciliar de recuperar a força histórica do cristianismo. Muito se falou da visão de Ratzinger do Concílio Vaticano II; também eu mesmo o fiz, ao tratar da análise que Ratzinger fez da hermenêutica conciliar sobre o mundo de hoje, moderno. $^{21}$

\subsection{A fé eclesial contra a desinstitucionalização religiosa}

O Cardeal Ratzinger olha a história, no último prefácio, a partir de 1967. Ele, no entanto, dá um salto: mostra que depois de 1989 não surgiu um novo alento nem uma resposta frente ao ceticismo em relação aos grandes ideais. Ele lembra ali um fator importante que vem surgindo desde o fim da década de 60: "a religião voltou a ser moderna". ${ }^{22}$ Ratzinger faz referência ao movimento amplamente conhecido como "volta do sagrado", "revanche de Deus" que caracterizou a década de $60 .{ }^{23}$

Vejamos que a discussão agora está na religião (não só no cristianismo ocidental) e na sua relação com a modernidade. Ele diz que, agora, ninguém mais conta com o desaparecimento da religião. Mas esta era propriamente a tese daqueles que viam a secularização como emancipação (eliminação, supressão) da religião. ${ }^{24}$ Como podemos ver, Ratzinger se posiciona dentro do campo da sociologia da religião. Para ele, os anos posteriores à publicação da Introdução foram caracterizados pela busca do misticismo.

Ele discorda parcialmente - isso é fundamental - de uma tese importante e amplamente compartilhada: "Muitos se queixam reclamando que a nova demanda por religião estaria, em grande parte, passando ao largo das igrejas cristãs tradicionais. Instituições e dogmas estão atrapalhando", ${ }^{25}$

\footnotetext{
${ }^{21}$ ASSUNÇÃO, R. A., Bento XVI, a Igreja Católica e o "espírito da modernidade".

${ }^{22}$ RATZINGER, J., Introdução ao Cristianismo, p. 16.

${ }^{23}$ MARTELLI, S., A religião na sociedade pós-modernidade.

${ }^{24}$ MONOD, J.-C., La querelle de la sécularisation, p. 24-30.

${ }^{25}$ RATZINGER, J., Introdução ao Cristianismo, p. 16.
} 
ao que ele diz que "não daria apoio incondicional a essa reclamação". ${ }^{26}$

O lamento a que Ratzinger faz referência não era infundado, mas baseado num diagnóstico sociológico que se popularizou a partir da década de 60. Exatamente em 1967 foi lançado o livro do sociólogo esloveno Thomas Luckmann, A religião invisivel, publicado nos EUA (e só em 1991 na Alemanha), ${ }^{27}$ mas com ampla repercussão na época em terras germânicas.

Luckmann criticava a sociologia da religião de então por não fazer a devida distinção entre " "igreja' e 'religião" ${ }^{28}$ e por crer que a religião "só é acessível à análise científica na medida em que se torna organizada e institucionalizada". ${ }^{29}$ Segundo ele, ela se caracterizava como uma "sociologia de paróquia" ${ }^{30}$ Sua tese era precisamente a da subjetivação das crenças, ou melhor, a passagem de uma religião de Igreja (sem o seu necessário desaparecimento), tradicional, "oficial" para uma nova forma social de religião: a religiosidade individual. ${ }^{31}$ Em outros termos, acontece a "privatização da religião", o que permite ao indivíduo que construa a sua existência individual ao construir também um cosmos sagrado a partir de elementos diversos e livremente amalgamados e justapostos (a bricolagem). A religiosidade é cada vez menos institucional ou até anti-institucional. A secularização pode representar o declínio da vinculação ou da frequência às igrejas, mas não representa necessariamente a eliminação da crença no nível individual, subjetivo.

Ratzinger discorda da reclamação, como vimos - contrapondo-se, sim, à absolutização do diagnóstico - de que a há um longo e inexorável processo de desinstitucionalização religiosa ou de "deseclesiastização" da prática religiosa. Chama atenção que ele contraria aqueles que veem as Jornadas Mundiais da Juventude como mero impulso passageiro. Ele cita explicitamente a JMJ de Paris, ocorrida em 1997, que foi objeto de estudo da socióloga francesa Danièle Hervieu-Léger ${ }^{32}$ em $O$ peregrino e o convertido. A religião em movimento.

\footnotetext{
${ }^{26}$ RATZINGER, J., Introdução ao Cristianismo, p. 16.

${ }^{27}$ Para mais informações sobre a recepção da obra, KNOBLAUCH, H., Apresentação. Outro estudo sobre o pensamento de T. Luckmann está em MARTELLI, S., A religião na sociedade pós-moderna, p. 301-306.

${ }^{28}$ LUCKMANN, T., A religião invisível, p. 43.

${ }^{29}$ LUCKMANN, T., A religião invisível, p. 43-44.

${ }^{30}$ LUCKMANN, T., A religião invisível, p. 45.

${ }^{31}$ LUCKMANN, T., A religião invisível, p. 91-98.

${ }^{32}$ Hervieu-Léger, teórica da "modernidade religiosa", afirma que com o catolicismo está se dando um processo de exculturação, uma saída cultural (e não somente política) do catolicismo (HERVIEU-LÉGER, D., Catholicisme, la fin d'un monde), uma desarticulação entre o catoli-
} 
Hervieu-Léger se apoia precisamente na "transitoriedade" de experiências de massa religiosas como as JMJ. Ela defende que hoje se assiste a uma crise da transmissão da memória religiosa. Ela lida com um conceito de modernidade religiosa ligado a um conceito de secularização cujo significado é, por um lado, "a dispersão das crenças e das condutas"33 e, por outro, da "desregulação institucional da religiosidade", ${ }^{34}$ por outro. Essa é uma nova face da religião, a sua dimensão moderna.

Importa, aqui, mostrar a que tipo de teses sociológicas Ratzinger faz referência (embora ele não cite diretamente autores como os que estou colocando no horizonte do leitor). O então cardeal alemão estabelece, assim,

cismo e a cultura, inserida no amplo processo que caracteriza a modernidade religiosa que é a "desinstitucionalização religiosa" (HERVIEU-LÉGER, D., O peregrino e o convertido). Por isso, "o problema que atinge o Catolicismo causado pela crise estrutural da instituição do religioso não está ligado primordialmente à estrutura da autoridade e à maneira de gestão particular da Igreja romana. Concerne, acima de tudo [...] à possibilidade de que o 'capital da memória' que constitui cada uma das 'grandes religiões' possa continuar a construir tradição na sociedade moderna, ou seja, que possa representar a continuidade de uma grande descendência de fé, transcendendo as diferentes comunidades onde esta descendência está atualizada de maneira plural no tempo e no espaço" (HERVIEU-LÉGER, D., Catholicisme, la fin d'un monde, p. 93). Portanto, a cultura moderna não abre mais espaços para a penetração da lógica católica. Essa exculturação do catolicismo, no entanto, não representa o fim, a eliminação da crença, mas "ela passa, ao contrário, para uma proliferação do crer que explode dos grandes códigos prescritos pelas instituições religiosas e obrigando estas a um considerável remanejamento" (HERVIEU -LÉGER, D., Catholicisme, la fin d'un monde, p. 20). Esse processo, segundo a autora, articulouse em três momentos: a laicização, pela perda do lugar central da Igreja na Revolução Francesa (1789) em favor do Estado que transfigura o religioso em soberania; a secularização interna, a partir da qual "a Igreja viu-se progressivamente expulsa não somente da posição central que ocupava na sociedade, mas também da empresa englobante sobre comportamentos coletivos e sobre as consciências individuais" (HERVIEU-LÉGER, D., Catholicisme, la fin d'un monde, p. 70), culminando no chamado catolicismo intransigente. Há, pois, uma mudança da mentalidade religiosa, voltada mais para a individualização a crença (HERVIEU-LÉGER, D., Catholicisme, la fin d'un monde, p. 81). Enfim, o terceiro momento é o da ultramodernidade, que se manifesta em quatro tendências: o individualismo e a exaltação da subjetividade, a reorganização do tempo devido ao acesso acelerado às informações, uma nova relação com a natureza engendrada pelos avanços tecnológico-científicos e, enfim, um contratualização das relações sociais, que coloca regras racionais no lugar de valores (HERVIEU-LÉGER, D., Catholicisme, la fin d'un monde, p. 86-88). Para a autora, a Igreja Católica "perdeu sua capacidade de circunscrever os indivíduos numa cultura específica, organizada por referências comuns de sentido dadas do alto" (HERVIEU-LÉGER, D., Catholicisme, la fin d'un monde, p. 267), o que a levaria a buscar um novo regime de autoridade e de institucionalidade, obrigando a dialogar com o mundo cultural na qual ela está insere, mas o qual ela não determina mais.

${ }^{33}$ HERVIEU-LÉGER, D., O peregrino e o convertido, p. 21.

${ }^{34}$ HERVIEU-LÉGER, D., O peregrino e o convertido, p. 21-22. 
o seu posicionamento pessoal frente ao diagnóstico das ciências da religião. Assim é que Ratzinger testemunha que eventos como as JMJ produzem frutos de longa duração em termos de adesão à Igreja: "Que ninguém diga que isso é só uma coisa passageira". ${ }^{35}$

O desafio que permanece é este: a fé cristã é uma fé eclesial; ela passa por um nós de uma comunidade que precede o indivíduo, que nunca está isolado. A fé - a vida que contém, os conteúdos cridos e celebrados que engloba deve ser sempre recebida e comunicada; ela exige, reclama uma traditio. Comporta magistério, funda-se na ortodoxia. E transmitir uma fé que implica necessariamente a pertença a um corpo num contexto de crença num religioso individual é, portanto, um dos maiores desafios da Igreja em nosso tempo.

\subsection{O crescimento das religiões orientais e suas consequências para a fé em Deus e em Cristo}

Depois de 1967 - para voltarmos ao prefácio - houve uma redescoberta no âmbito ocidental de religiões como o budismo e o hinduísmo. Uma observação, destarte, deve ser feita sobre a análise ratzingeriana do cenário religioso mundial.

Um ponto fundamental da leitura de Ratzinger é que as religiões orientais trazem consigo uma imagem impessoal de Deus, o que implica um afastamento do mundo, ${ }^{36}$ a sua superação e do sofrimento que o caracteriza. ${ }^{37}$ Um Deus impessoal não gera ação no mundo. Ou seja, como o livro se preocupa com "a situação atual da fé em Deus e em Cristo", ${ }^{38}$ com ele Ratzinger quer mostrar que o avanço de religiões asiáticas no ocidente dificulta a compreensão das premissas básicas da fé cristã, fundadas na crença em um Deus pessoal, que em Cristo assume o sofrimento humano, para redimi-lo. Nesse sentido o último prefácio apresenta os desafios que a teologia cristã - sobretudo a cristologia tem que enfrentar quando pretende ser fiel ao imperativo anunciar ao mundo a fé no Deus único e verdadeiro, que em Cristo tem um rosto.

\footnotetext{
${ }^{35}$ RATZINGER, J., Introdução ao Cristianismo, p. 17.

${ }^{36}$ Para um aprofundamento da visão do teólogo alemão sobre o budismo e o hinduísmo no debate político acerca da conservação ou da transformação do mundo, RATZINGER, J., Europa.

${ }^{37}$ Com isso Ratzinger se aproxima da abordagem do sociólogo alemão Max Weber (WEBER, M., Ensayos sobre la sociología de la religión, v.II), que estudou precisamente a relação entre a imagem de Deus e a postura adotada diante do mundo.

${ }^{38}$ RATZINGER, J., Introdução ao Cristianismo, p. 20.
} 


\section{Duas grandes rupturas culturais: 1968 e 1989}

Agora, nesta exposição, é conveniente que nos detenhamos com mais vagar em duas datas centrais para Ratzinger, as quais são emblemáticas de uma nova orientação ideológica que logrou se impor no mundo e frente a qual o cristianismo teve (e ainda tem) de se posicionar, se não quer definhar lamentavelmente e ser reduzido a um artefato de museu. Logo nas primeiras linhas da atual edição da Introdução o cardeal Ratzinger fazia menção a duas datas que, para ele, marcam duas viragens fundamentais para a emergência do "mundo" no qual o cristianismo deve ser anunciado (enquanto é abertamente descartado). Ou melhor dizendo, o homem que Ratzinger quer introduzir no cristianismo é filho de 1968 e 1989. Tratemos de cada uma dessas datas.

Em 1968 se assiste à rebelião da geração insatisfeita com o pós-guerra e frustrada com a herança cristã, que não teria trazido o mundo melhor esperado. O marxismo, ou nas palavras de Ratzinger, a "doutrina marxista da salvação" 39 seria a resposta aos anseios desta geração. ${ }^{40}$ Mas em 1989, outra data crucial, com a queda do regime comunista soviético ficou a sensação de frustração e uma grande perplexidade (embora persista ainda a crença na validade do discurso marxista), que teve como consequência a resignação no pragmatismo e a eliminação dos fundamentos éticos do agir.

Antes de prosseguir é preciso recordar que Ratzinger tratou dos desenvolvimentos pós-89 no seu livro Wendezeit für Europa? Diagnosen und Prognosen, de 1991, publicado em língua portuguesa - no ano 1993 - como A Igreja e a Nova Europa. Ali ele trata da crise do marxismo como uma interpelação para o Ocidente. Com os eventos de 1989 o marxismo, visto como uma "interpretação totalizante da realidade e como guia do agir histórico, foi completamente desmentido". " Suas promessas de liberdade, igualdade e bemestar foram desmascaradas. A falsidade da interpretação do mundo marxista veio à tona quando "aquele materialismo que quis conceber redutivamente $\mathrm{o}$ espírito como pura consequência das estruturas materiais, mera superestrutura do sistema econômico, foi definitivamente desmentido". ${ }^{42}$ E dizia mais:

\footnotetext{
${ }^{39}$ RATZINGER, J., Introdução ao Cristianismo, p. 11. O cariz escatológico do marxismo está nitidamente desenvolvido em RATZINGER, J., Escatologia, p. 29-30.

${ }^{40}$ Um estudo sobre a visão de Ratzinger sobre o marxismo está em Assunção (ASSUNÇÃO, R.

A., O papa precisa do marxismo?, p. 1042-1059).

${ }^{41}$ RATZINGER, J., A Igreja e a nova Europa, p. 58.

${ }^{42}$ RATZINGER, J., A Igreja e a nova Europa, p. 58.
} 
A pretensão de construir o homem perfeito e a sociedade perfeita mediante receitas de tipo estrutural é o núcleo específico do materialismo contemporâneo, e este núcleo provou que é falso. Quem se fia no valor mecânico acima do valor espiritual, eterno, acaba por ver que errou. ${ }^{43}$

Creio que para entender melhor este contexto mundial no qual Ratzinger insere o seu discurso sobre a Introdução no novo milênio é preciso recorrer ao seu pontificado. Ele explica o impacto das duas datas sobre a missão da Igreja no seu encontro com o Clero de Belluno-Feltre e Treviso, no dia 24 de julho de 2007. Na ocasião, um sacerdote que viveu os anos do Concílio e de sua imediata recepção questionava o então Papa alemão quanto as muitas expectativas geradas pelo Vaticano II que não se realizaram. Neste dia, Bento XVI parte, na sua análise, das duas datas que ele analisa brevemente no novo pórtico da Introdução no fim do segundo milênio. Ele recordava sua própria experiência conciliar, mostrando que a visão do Vaticano II era, sim, a de um "novo Pentecostes", ${ }^{44}$ um reencontro entre Igreja e mundo. Observamos que, de fato, no fulcro do Concílio estava a relação entre Igreja e modernidade, pois o Vaticano II queria superar o afastamento de ambos nos séculos anteriores. Mas este mundo estava em profunda mudança. Enquanto a Igreja se reformava o mundo sofria as suas revoluções.

Ele recorda na mesma ocasião - o que fez já na sua obra Teoria dos princípios teológicos ${ }^{45}$ - que mesmo ao Concílio de Niceia não se seguiu um período de paz na Igreja, mas de verdadeira confusão, como testemunhou São Basílio. Mas é importante frisar que há desenvolvimentos históricos que não são resultado do Concílio e que ajudam a compreender o caminho tomado pelo mundo contemporâneo sem que ele seja resultado direto do Vaticano II. Para entendê-lo, cito Bento XVI textual e longamente, para retomar depois alguns pontos de sua explanação das duas datas aqui estudadas:

No concreto do pós-Concílio devemos constatar que existem duas grandes suspensões históricas. No pós-Concílio, a suspensão de 1968, o início ou a explosão ousaria dizer da grande crise cultural do Ocidente. Tinha terminado a geração do pós-guerra, uma geração que depois de todas as

\footnotetext{
${ }^{43}$ RATZINGER, J., A Igreja e a nova Europa, p. 59.

${ }^{44}$ BENTO XVI, PP., Encontro do Papa Bento XVI com o Clero das Dioceses de Belluno-Feltre e Treviso.

${ }^{45}$ RATZINGER, J., Teoría de los principios teológicos. A edição usada aqui é de 1985.
} 
destruições e vendo o horror da guerra, do combater-se e verificando o drama destas grandes ideologias tinham realmente levado as pessoas à voragem da guerra, tinham redescoberto as raízes cristãs da Europa e começado a reconstruir a Europa com estas grandes inspirações. Mas tendo terminado esta geração viram-se também todas as falências, as lacunas desta reconstrução, a grande miséria do mundo e começa assim, explode, a crise da cultura ocidental que pretende mudar radicalmente. Diz: não criámos, em dois mil anos de cristianismo, o mundo melhor. Devemos recomeçar de zero de modo absolutamente novo; o marxismo parece a receita científica para criar finalmente um mundo novo. E neste digamos grave, grande confronto entre a nova, sadia modernidade querida pelo Concílio e a crise da modernidade, tudo se torna difícil como depois do primeiro Concílio de Niceia. Uma parte tinha a opinião de que esta revolução identificava esta nova revolução cultural marxista com a vontade do Concílio; dizia: este é o Concílio. No papel os textos ainda são um pouco antiquados, mas por detrás das palavras escritas está este espírito, esta é a vontade do Concílio, assim devemos fazer. E por outro lado, naturalmente, a reação: destruir assim a Igreja. A reação digamos absoluta contra o Concílio, o anti-Concílio e digamos a tímida, humilde busca de realizar o verdadeiro espírito do Concílio. ${ }^{46}$

Mais uma vez aparece o marxismo, que pretende criar um "mundo novo". Não é à toa que uma observação deste tipo seja perfeitamente coerente com a visão de Bento XVI expressa na sua encíclica Spe salvi sobre a esperança cristã. Também ali o Papa alemão mostra que Marx conclamava o proletariado a ser agente de criação de uma nova humanidade, "redimida" da exploração (o "pecado" por excelência) por suas próprias forças. ${ }^{47}$ Mas prossigamos com a resposta de Bento XVI, que salta duas décadas para chegar ao fim dos anos 80 :

\footnotetext{
${ }^{46}$ BENTO XVI, PP., Encontro do Papa Bento XVI com o Clero das Dioceses de Belluno-Feltre e Treviso.

${ }^{47}$ Cito textualmente o n. 20 da Spe salvi: "Depois da revolução burguesa de 1789, tinha chegado a hora para uma nova revolução: a proletária. O progresso não podia limitar-se a avançar de forma linear e com pequenos passos. Urgia o salto revolucionário. Karl Marx recolheu este apelo do momento e, com vigor de linguagem e de pensamento, procurou iniciar este novo passo grande e, como supunha, definitivo da história rumo à salvação, rumo àquilo que Kant tinha qualificado como o 'reino de Deus'. Tendo-se diluída a verdade do além, tratar-se-ia agora de estabelecer a verdade de aquém. A crítica do céu transforma-se na crítica da terra, a crítica da teologia na crítica da política. O progresso rumo ao melhor, rumo ao mundo definitivamente bom, já não vem simplesmente da ciência, mas da política".
} 
E depois a segunda suspensão em 1989. A queda dos regimes comunistas, mas a resposta não foi o regresso à fé, como se podia talvez esperar, não foi a redescoberta de que a Igreja com o Concílio autêntico tinha dado a resposta. Ao contrário, a resposta foi o ceticismo total, a chamada pós-modernidade. Nada é verdadeiro, cada um deve ver como viver, afirma-se um materialismo, um ceticismo pseudo-racionalista cego que termina na droga, termina em todos estes problemas que conhecemos e de novo fecha os caminhos à fé, porque é tão simples, tão evidente. Não, não há nada de verdadeiro. A verdade é intolerante, não podemos ir por este caminho. Eis: nestes contextos de duas rupturas culturais, a primeira, a revolução cultural de 1968, a segunda, a queda, poderíamos dizer, no niilismo depois de 1989, a Igreja com humildade, entre as paixões do mundo e a glória do Senhor, empreende o seu caminho. ${ }^{48}$

Bento XVI fala de suspensões (cesure no original italiano: quebras, rupturas) históricas. Em 1968, a "queda" no marxismo; depois de 1989, atrelada à queda do comunismo veio a queda no ceticismo e no nihilismo. Ratzinger frisa que esse ceticismo não deu margem a um renascimento da fé. Este ceticismo é, no fim das contas, outro lado da moeda do pragmatismo e da eliminação dos fundamentos éticos dos quais Ratzinger fala na Introdução: sem verdade - isso é a "pós-modernidade", sem os fundamentos da lei moral natural resta ao homem a descrença, a dúvida e, é claro, a possibilidade de agir apenas guiado por critérios de utilidade e eficácia.

\section{Conclusão}

O exame realizado evidenciou que o teólogo Ratzinger estava o tempo todo atento às correntes de pensamento e às doutrinas religiosas que representam um desafio para o anúncio da fé em Deus e em seu Filho Jesus Cristo. Não basta, para ele, olhar para o dogma, para o Símbolo Apostólico (e, é claro, para as Sagradas Escrituras); é preciso olhar o mundo que deverá ouvilo e ser convidado a crer nele.

Ratzinger trava um debate religioso e político para que o discurso teológico continue plenamente forte, sólido, competente frente às vozes discordantes do mundo do pensamento. Ele sabe que o mundo é outro: a cristandade acabou. A

${ }^{48}$ BENTO XVI, PP., Encontro do Papa Bento XVI com o Clero das Dioceses de Belluno-Feltre e Treviso. 
fé não é mais pressuposta, não é mais um dado da realidade. Esta consciência é fundamental para anunciar o núcleo do cristianismo - um encontro com uma Pessoa - ao mundo.

Assim é que a Introdução ao Cristianismo continua como um instrumento válido e atual para introduzir jovens estudantes e tantos outros - muitos "neopagãos" é a Igreja, como se expressava o teólogo Karl Adam (1876-1966), também ele bávaro, que inspirou a obra em questão com seu livro $A$ essência do catolicismo (1924).$^{50}$ Ela foi e continua a ser um raio da luz da fé da Igreja a iluminar muitos que buscam ser introduzidos no que é o cristianismo e um verdadeiro pão que pode nutrir a muitos que têm fome da verdade que salva.

\section{Referências bibliográficas}

ADAM, K. A essência do catolicismo. Petrópolis: Vozes, 1942.

ASSUNÇÃO, R. A. O Papa precisa do marxismo? A incompatibilidade entre a fé cristã e a fé marxista. Horizonte, v. 10, n. 27, p. 1042-1059, 2012.

ASSUNÇÃO, R. A. Bento XVI, a Igreja Católica e o "espírito da modernidade". Uma análise da visão do Papa Teólogo sobre o "mundo de hoje. Campinas: Ecclesiae; São Paulo: Paulus, 2018.

BENTO XVI, PP. Encontro do Papa Bento XVI com o Clero das Dioceses de Belluno-Feltre e Treviso. Igreja Santa Justina Mártir, Auronzo di Cadore, 24 julho 2007. Disponível em: <http://w2.vatican.va/content/benedict-xvi/ pt/speeches/2007/july/documents/hf_ben-xvi_spe_20070724_clero-cadore. html>. Acesso em: 18 jul. 2018.

BENTO XVI, PP. Carta Encíclica Spe salvi sobre a esperança cristão, 30 de novembro de 2007. Disponível em: <http://w2.vatican.va/content/ benedict-xvi/pt/encyclicals/documents/hf_ben-xvi_enc_20071130_spe-salvi. html >. Acesso em: 22 ago. 2018.

BLANCO, P. Benedicto XVI. El Papa alemán. Barcelona: Planeta Testimonio, 2010.

CHARAMSA, K.; CAPIZZI, N. La voce dela fede cristiana. Introduzione

${ }^{49}$ RATZINGER, J., O novo povo de Deus, p. 297-309.

${ }^{50}$ ADAM, K., A essência do catolicismo. A publicação brasileira é de 1942. 
al cristianesimo di Joseph Ratzinger - Benedetto XVI, 40 anni dopo. Roma: Ateneo Regina Apostolorum, 2009.

GUERRIERO, E. Servitore di Dio e dell'umanità. La biografia de Benedetto XVI. Milano: Mondadori, 2016.

GIBELlinI, R. A Teologia do Século XX. São Paulo: Loyola, 2012.

HERVIEU-LÉGER, D. Catholicisme, la fin d'un monde. Paris: Bayard, 2003.

HERVIEU-LÉGER, D. O peregrino e o convertido. A religião em movimento. Petrópolis: Vozes, 2008.

KNOBLAUCH, H. Apresentação: “A dissolução da religião no religioso”. In: LUCKMANN, T. A religião invisível. São Paulo: Olho D’Água / Loyola, 2014. p. 5-33.

LUCKMANN, T. A religião invisível. São Paulo: Olho D’Água / Loyola, 2014.

MARTELLI, S. A religião na sociedade pós-moderna: entre secularização e dessecularização. São Paulo: Paulinas, 1995.

METZ, J. B. Teologia Política. Porto Alegre: Escola Superior de Teologia São Lourenço de Brindes; Caxias do Sul: Universidade de Caxias do Sul, 1976.

MOLTMANN, J. Teologia da Esperança. Estudos sobre os fundamentos e as consequências de uma escatologia cristã. São Paulo: Herder, 1971.

MONDIN, B. Os teólogos da libertação. São Paulo: Paulinas, 1980.

MONOD, J.-C. La querelle de la sécularisation: de Hegel a Blumenberg. Paris: Vrin, 2002.

RATZINGER, J. O novo povo de Deus. São Paulo: Paulinas, 1974.

RATZINGER, J. Teoría de los principios teológicos. Barcelona: Herder, 1985.

RATZINGER, J. A Igreja e a nova Europa. Lisboa: Verbo, 1993.

RATZINGER, J. Europa. Os seus fundamentos hoje a amanhã. Apelação: Paulus, 2005.

RATZINGER, J. Introdução ao Cristianismo. Preleções sobre o Símbolo Apostólica. Com um novo ensaio introdutório. São Paulo: Loyola, 2005. 
RATZINGER, J. Lembranças da minha vida: autobiografia parcial (19271977). São Paulo: Paulinas, 2006.

RATZINGER, J. Obras Completas IV. Introducción al cristianismo. Fe Bautismo - Seguimiento. Madrid: BAC, 2018.

RATZINGER, J. Escatologia. Morte e vida eterna. São Paulo: Molokai, 2020.

RATZINGER, J.; SEEWALD, P. O Sal da Terra. O Cristianismo e a Igreja Católica no limiar do Terceiro Milênio. Um diálogo com Peter Seewald. Rio de Janeiro: Imago, 1997.

RATZINGER, J.; SEEWALD, P. Deus e o mundo. Fé e vida em nosso tempo. Uma conversa com Peter Seewald. São Paulo: Molokai, 2020.

VALENTE, G. Ratzinger Professore. Gli anni dello studio e dell'insegnamento nel recordo dei colleghi e degli allievi (1946-1977). Cinisello Balsamo (Milano): San Paolo, 2008.

WEBER, M. Ensayos sobre la sociología de la religión. Madrid: Taurus, 1998. v.II.

Rudy Albino de Assunção

Doutor em Sociologia Política pela Universidade Federal de Santa Catarina Docente de Filosofia e Teologia no Centro Universitário Católica de Quixadá Quixadá / CE - Brasil E-mail: rudyalbino@unicatolicaquixada.edu.br

Recebido em: 21/01/2019

Aprovado em: 20/05/2020 